\title{
Somatotype Components, Aerobic Fitness and Grip Strength in Kuwaiti Males and Females
}

\author{
Jasem Ramadan Alkandari, Mario Barac Nieto \\ Department of Physiology, Faculty of Medicine, Kuwait University, Kuwait City, Kuwait \\ Email: ramadan@hsc.edu.kw
}

How to cite this paper: Alkandari, J.R. and Barac Nieto, M. (2016) Somatotype Components, Aerobic Fitness and Grip Strength in Kuwaiti Males and Females. Health, 8, 1349-1355.

http://dx.doi.org/10.4236/health.2016.813135

Received: May 4, 2016

Accepted: October 14, 2016

Published: October 17, 2016

Copyright $\odot 2016$ by authors and Scientific Research Publishing Inc. This work is licensed under the Creative Commons Attribution International License (CC BY 4.0).

http://creativecommons.org/licenses/by/4.0/

(c) (i) Open Access

\section{Abstract}

Introduction and Objective: We investigated the association of endo-, meso- and ecto-morphic components of somatotype with aerobic power, mid-trunk flexibility and grip strength. Methods: Healthy male $(n=226)$ and female $(n=86)$ subjects, aged 9 55 years, sedentary $(n=154)$ or participating in sports $(n=158)$ were studied. Anthropometrics (height, weight, 8 skin folds, arm and calf circumferences, elbow and knee diameters), maximal exercise $\mathrm{O}_{2}$ uptake, mid trunk flexibility, right and left grip strength were measured. Results: Sedentary adult females were endomorphic with mesomorph tendency, and had low aerobic power $(27.8 \pm 0.6 \mathrm{ml} / \mathrm{Kg} \cdot \mathrm{min})$ and low $(48.7 \pm 1 \mathrm{Kg})$ grip strength. Sedentary males (young and adults) and Sports adult males were mesomorph with endomorphic tendency. Sports junior males were balanced mesomorph. Aerobic power was $54.1 \pm 0.9 \mathrm{ml} / \mathrm{Kg} \cdot \mathrm{min}$ in sports young males, $53.8 \pm 0.9$ $\mathrm{ml} / \mathrm{Kg} \cdot \mathrm{min}$ in sports adult males, $41.2 \pm 4.3 \mathrm{ml} / \mathrm{Kg} \cdot \mathrm{min}$ in sedentary young males, and $39.5 \pm 1 \mathrm{ml} / \mathrm{Kg} \cdot \mathrm{min}$ in sedentary adult males. Grip strength was $89.9 \pm 1.7 \mathrm{Kg}$ in sports adult males, $86.7 \pm 2 \mathrm{Kg}$ in sedentary adult males, $75.6 \pm 2.2 \mathrm{Kg}$ in sports junior males and $52 \pm 9.1 \mathrm{Kg}$ in young sedentary males. Step-wise multiple regression analysis of somatotype components on aerobic power revealed dominant negative contribution ( $\mathrm{P}$ $<0.001)$ of endomorphy $\left(\mathrm{r}^{2}=0.57,57 \%\right)$, and small but significant positive contributions of mesomorphy (0.6\%) and ectomorphy (0.6\%): Aerobic power $=[56.1-4.3$ (endomorphy) + (mesomorphy) + 1.4 (ectomorphy)] \pm 9.1 SEE. Height and somatotype components accounted for $69 \%$ of the variance $\left(\mathrm{R}^{2}\right)$ in grip strength; height had greatest contribution (60\%): Grip Strength $=[1.7$ (Height) -6.5 (ectomorphy) -3.4 (endomorphy) - 2 (mesomorphy) - 200] \pm 12.9 SEE. Measured variables accounted for $<2 \%$ of flexibility variance. Conclusion: Endomorphy contributes greatly and negatively to variance in aerobic power. Body height was the anthropometric variable with the greatest positive association with the variance in grip strength. Flexibility appears to be unrelated to somatotype components. 


\section{Keywords}

Maximal Oxygen Uptake, Endomorphy, Mesomorphy, Ectomorphy, Grip Strength

\section{Introduction}

Body built is to a large extent genetically determined [1]. Correlations of somatotype components between siblings are significant, and tend to be higher in the case of mesomorphy than in the case of endomorphy which apparently depends more on environmental influences, particularly in females [1]. High inheritabilities for mesomorphy and ectomorphy have been reported in twin studies at adolescence and are maintained in adulthood. For endomorphy, however, heritability at adulthood may be considerably lower than reported in studies on adolescent twins [2].

Body type has important influence on body composition [3]. For example, ectomorphs were found to have less Fat Free Mass (FFM), less Body Cell Mass (BCM) and lower absolute maximal oxygen uptake than meso- or endo-morphs [3]. Certain physically active subjects have systematic deviations in the density of the FFM independently of differences in muscularity or musculoskeletal development [4].

Top category weight lifters tend to have large body mass with high levels of mosomorphy and endomorphy. By contrast elite long distance runners tend to have small body mass, less endomorphy than mesomorphy and dominant ectomorphy [5]. Anthropometric and physiological differences exist among soccer players who play in different positions and the differences fit with their different workloads in the game [6]. The physically active subjects may select their sport modality according to their endowment and develop more specific physical and functional characteristics as a consequence of training.

To some degree, somatotype, and particularly its endomorphic and mesomorphic components, may be affected by the type and daily levels of energy expenditure and intake that impinge on body composition as well as on aerobic fitness and strength.

Studies in pubertal twins show that training can favor aerobic power $\left(\mathrm{VO}_{2} / \mathrm{Kg}\right.$ at lactate threshold) as well as aerobic capacity $\left(\mathrm{VO}_{2 \max } / \mathrm{Kg}\right)$, but has no effect on absolute $\mathrm{VO}_{2 \max }$. Thus, the effect of aerobic training in these young subjects is mostly on body composition (reduced \% body fat) and not on the mass of oxygen delivered and extracted by the active muscles. This may be also true in very active adult males or females. However, in sedentary subjects, training has significant effects on oxygen delivery and extraction and on absolute $\mathrm{VO}_{2 \max }[7]$.

Inherited factors have a strong effect on the extent of the adaptations to training ( $45 \%$ to $70 \%)$, and genotype-training interactions explain a small $(10 \%-20 \%)$, but prominent part of these adaptations [8]. Indeed, subjects with certain somatotypes (balanced mesomorphs and meso-ectomorphs) show greatest improvements in aerobic capacity with training indicating differences in the susceptibility to training according to the somatotype [9]. 
The maximal ability to consume oxygen during exercise is also largely genetically determined although its decline with age may be modified by training and/or daily levels of energy expenditure and intake. By contrast, the aerobic capacity or relative $\mathrm{VO}_{2 \max }(\mathrm{ml} / \mathrm{Kg} \cdot \mathrm{min})$ depends in addition, on body composition characteristics such as \% body fat and \% muscle in the FFM, both of which may be modified by training, nutrition and hormones.

The studies mentioned above suggest that the somatotype component most susceptible to environmental influences and that which may have the strongest relationship to modifiable health-related fitness characteristic such as aerobic capacity is endomorphy. Indeed, aerobic capacity has been found to be inversely dependent on anthropometric parameters (\% fat, BMI) more in obese than in non-obese women, while grip strength was directly dependent on body mass, more in obese than in lean women [10].

In this study we investigate the relationships of endo-, meso- and ecto-morphic components of somatotype to aerobic capacity, flexibility and grip strength in adult Kuwaiti subjects.

\section{Methods}

Healthy male $(\mathrm{n}=226)$ and female $(\mathrm{n}=86)$ subjects, 9 - 55 years of age, sedentary $(\mathrm{n}=$ $154)$ or participating in sports $(n=158)$ were studied.

They were selected according to:

1. Their physical activity level (active or sedentary);

2. Their gender;

3. Their age (young or adult);

4. Their health status (no physical or mental disabilities).

Anthropometrics (height, weight, 8 skin folds, arm and calf circumferences, and elbow and knee diameters) were determined as thoroughly described in previous studies from our laboratory [7].

Resting and maximal heart rates and blood pressures, maximal oxygen uptake $\left(\mathrm{VO}_{2 \max }\right)$ during treadmill exercise (Bruce's protocol), mid trunk flexibility, right and left grip strength were measured, as described in detail in previous published studies from this laboratory [7].

Endo-, meso- and ectomorphy, were calculated by using the Heath-Carter Anthropometric Somatotype method (J.E.L., Carter, 2002).

\section{Results}

Sedentary adult females were endomorphic with mesomorphic tendency. Sedentary males (young or adult) and sports adult males were mesomorphic with endomorphic tendency. Sports young males were balanced mesomorphs (Figure 1, Table 1).

Aerobic capacity $\left(\mathrm{VO}_{2 \max } \mathrm{ml} / \mathrm{kg} \cdot \mathrm{min}\right)$ was highest in sports young males $(54.1 \pm 0.9$ $\mathrm{ml} / \mathrm{Kg} \cdot \mathrm{min})$, similarly high in sportsadult males $(53.8 \pm 0.9 \mathrm{ml} / \mathrm{Kg} \cdot \mathrm{min})$, intermediate in sedentary young $(41.2 \pm 4.3 \mathrm{ml} / \mathrm{Kg} \cdot \mathrm{min})$ or adult males $(39.5 \pm 1.0 \mathrm{ml} / \mathrm{Kg} \cdot \mathrm{min})$ and lowest in sedentary adult females $(27.8 \pm 0.5 \mathrm{ml} / \mathrm{Kg} \cdot \mathrm{min})$ (Table 2$)$. 


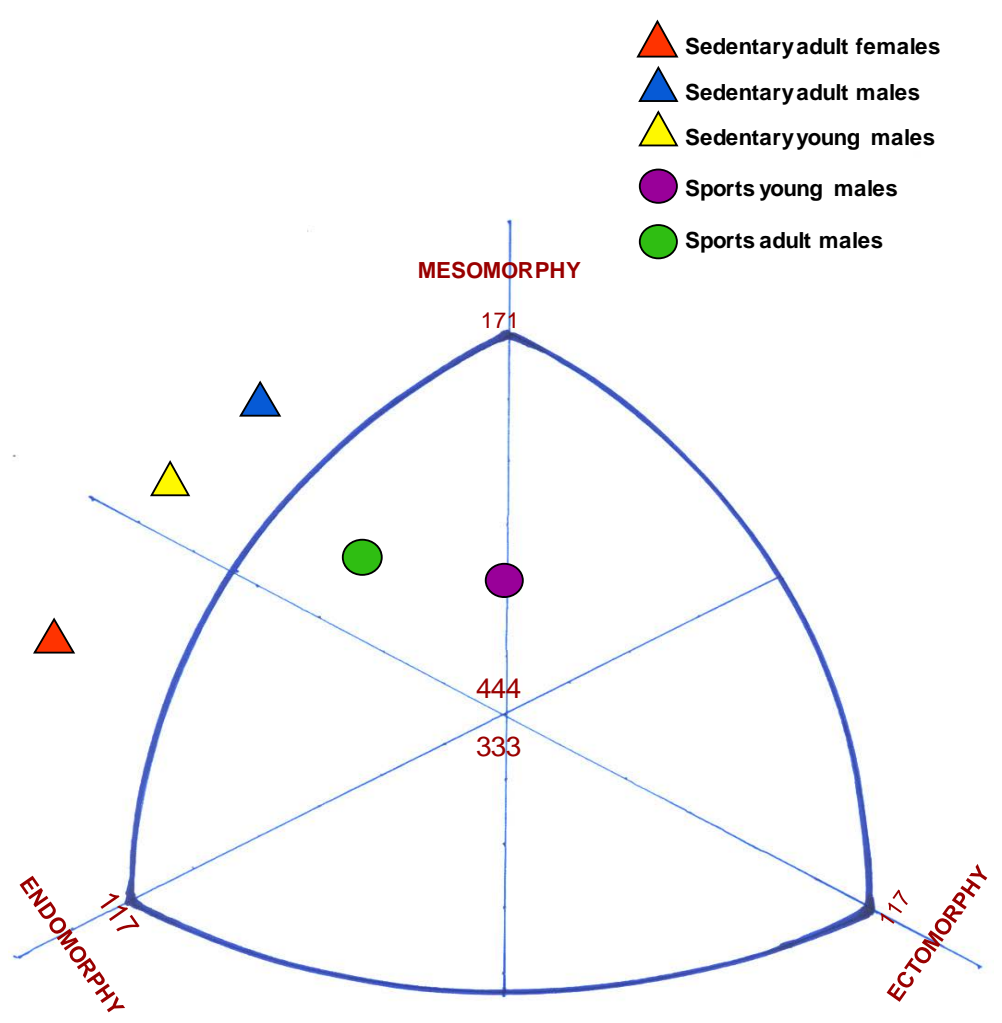

Figure 1. Somato-chart plots for means of Male Sedentary, Athlete, Young, Adult and Sedentary Adult Female groups.

Table 1. Age, height, weight and somatotype components in young and adult, sedentary and sports males and in sedentary adult females.

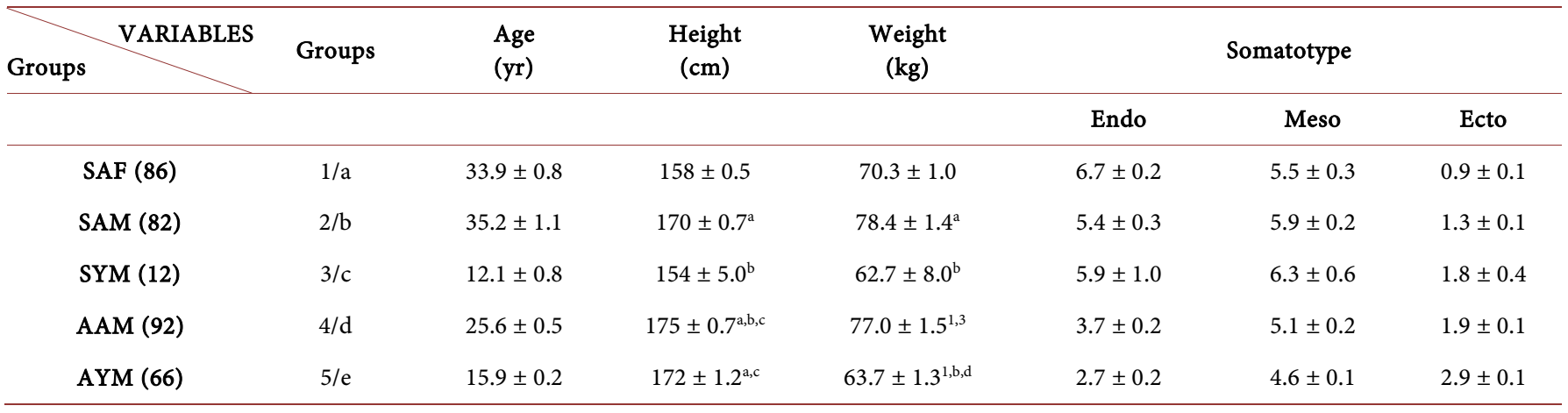

SAF: sedentary adult females; SAM: sedentary adult males; SYM: sedentary young males; AAM; sports adult males; AYM: sports young males. Numbers in parenthesis refer to number of subjects in each group. Values are mean and standard error of the means ( \pm SE). Significant between the groups at $p<0.05$, if group numbers are used $1 ; 2 ; 3 ; 4$. Significant between the groups at $\mathrm{p}<0.001$, if group letters are used $\mathrm{a} ; \mathrm{b} ; \mathrm{c} ; \mathrm{d}$.

Grip strength was highest in sports adult males $(89.9 \pm 1.7 \mathrm{Kg})$ or sedentary $(86.7 \pm 2$ $\mathrm{Kg})$; intermediate in sports young males $(75.6 \pm 2.2 \mathrm{Kg})$, and lowest in sedentary young males $(52 \pm 9.1 \mathrm{Kg})$ and in sedentary adult females $(48.7 \pm 1.0 \mathrm{Kg}$ ) (Table 2).

Flexibility was highest $(26.5 \pm 1.0 \mathrm{~cm})$ in sports adult males, similarly high $(26.3 \pm 0.9$ $\mathrm{cm})$ in sedentary adult females and in sedentary young males $(25.4 \pm 3.0 \mathrm{~cm})$, intermediate in sports young males $(21.1 \pm 1.0 \mathrm{~cm})$ and lowest $(18.2 \pm 1.0 \mathrm{~cm})$ in sedentary adult males (Table 2). 
Table 2. Aerobic capacity, Grip Strength and Flexibility in Sedentary and sports young and adult males and in Sedentary Adult Females.

\begin{tabular}{|c|c|c|c|c|c|c|c|}
\hline \multirow{2}{*}{ Groups } & \multirow[t]{2}{*}{ Groups } & \multirow{2}{*}{$\begin{array}{c}\mathrm{VO}_{2 \max } \\
(\mathrm{ml} / \mathrm{kg} / \mathrm{min})\end{array}$} & \multirow{2}{*}{$\begin{array}{l}\text { Strength } \\
(\mathrm{kg})\end{array}$} & \multirow[t]{2}{*}{ Flexibility $(\mathrm{cm})$} & \multicolumn{3}{|c|}{ Somatotype } \\
\hline & & & & & Endo & Meso & Ecto \\
\hline SAF (86) & $1 / \mathrm{a}$ & $27.8 \pm 0.7$ & $48.8 \pm 1.0$ & $26.3 \pm 0.9$ & $6.7 \pm 0.2$ & $5.5 \pm 0.3$ & $0.9 \pm 0.1$ \\
\hline SAM (82) & $2 / b$ & $39.6 \pm 1.0^{\mathrm{a}}$ & $86.8 \pm 2.0^{\mathrm{a}}$ & $18.2 \pm 1.0^{\mathrm{a}}$ & $5.4 \pm 0.3$ & $5.9 \pm 0.2$ & $1.3 \pm 0.1$ \\
\hline AAM (92) & $4 / \mathrm{d}$ & $53.8 \pm 0.9^{\mathrm{a}, \mathrm{b}, 3}$ & $89.9 \pm 2.0^{\mathrm{a}, \mathrm{c}}$ & $26.5 \pm 1.0^{\mathrm{b}}$ & $3.7 \pm 0.2$ & $5.1 \pm 0.2$ & $1.9 \pm 0.1$ \\
\hline AYM (66) & $5 / \mathrm{e}$ & $54.1 \pm 0.9^{\mathrm{a}, \mathrm{b}, \mathrm{c}}$ & $75.6 \pm 2.0^{\mathrm{a}, \mathrm{b}, 3, \mathrm{~d}}$ & $22.1 \pm 1.0^{1,2,4}$ & $2.7 \pm 0.2$ & $4.6 \pm 0.1$ & $2.9 \pm 0.1$ \\
\hline
\end{tabular}

SAF: sedentary adult females; SAM: sedentary adult males; SYM: sedentary young males; AAM; Sports adult males; AYM: Sports young males. Numbers in parenthesis refer to number of subjects in each group. Values are mean and standard error of the means ( \pm SE). Significant between the groups at $p<0.05$, if group numbers are used $1 ; 2 ; 3 ; 4$. Significant between the groups at $\mathrm{p}<0.001$, if group letters are used $\mathrm{a} ; \mathrm{b} ; \mathrm{c} ; \mathrm{d}$.

Step multiple regression analysis of aerobic capacity on somatotype components revealed a major contribution ( $\mathrm{p}<0.001$ ) of endomorphy $(57 \%)$, and minor contributions of mesomorphy $(0.6 \%)$ and ectomorphy $(0.6 \%)$, which accounted together for $58.4 \%\left(\mathrm{R}^{2}=0.584\right)$ of the variance in aerobic capacity (Figure 2$)$.

Height and somatotype components accounted for $69 \%$ (R2) of the variance in grip strength; height had the greatest contribution (60\%), endomorphy (4\%), ectomorphy (3.7\%) and particularly mesomorphy (1.6\%), had smaller contributions, (Figure 3 ).

Measured variables accounted for only $2.2 \%$ of flexibility variance $(\mathrm{p}>0.1)$.

\section{Discussion}

Endomorphy contributes greatly to the variance in aerobic capacity in this group of healthy Kuwaiti subjects, sedentary or participating in sports, males or females, young or adults. This likely reflects the negative influence of percent body fat, on aerobic capacity.

The higher aerobic capacity present in the more physically active males, independently of age, would suggest that it is consequent to the higher levels of physical activity compared to sedentary males. We cannot exclude however, the role of genetic influences since their genetic endowment may have influenced the decision of the subjects to regularly participate in sports.

Aerobic capacity was particularly low in sedentary adult females, corresponding to their high level of endomorphy. Since aerobic capacity in females can be almost as high as that in males [7], the severely low aerobic capacity observed in this group of sedentary adult females likely reflects their very sedentary life style and their high risk of exceeding energy needs, as reflected in their high endomorphy, even if the absolute level of energy intake is not high.

Somatotype components contribute significantly but to a much lesser extent than body height to the variance in grip strength. Surprisingly, mesomorphy contributed least to the variance in grip strength. Thus there may be a mechanical advantage to tall subjects for grip force development [11]. 


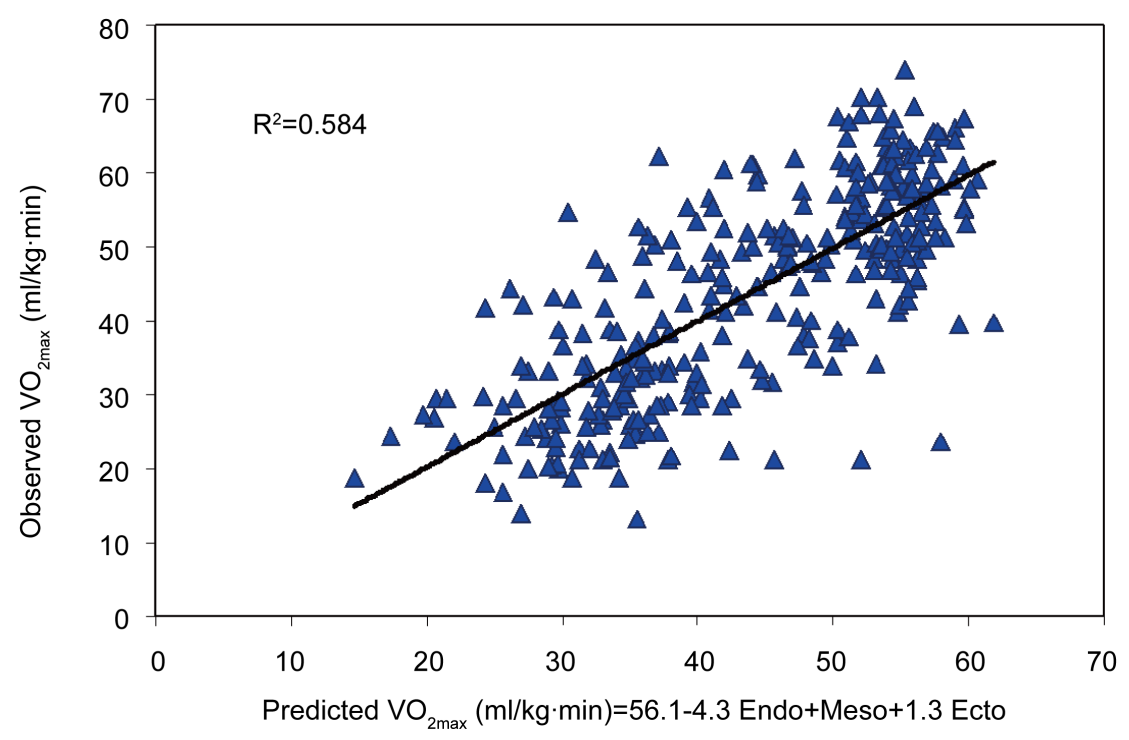

Figure 2. Correlation between measured $\mathrm{VO}_{2 \max }$ and $\mathrm{VO}_{2 \max }$ predicted from somatotype components [12].

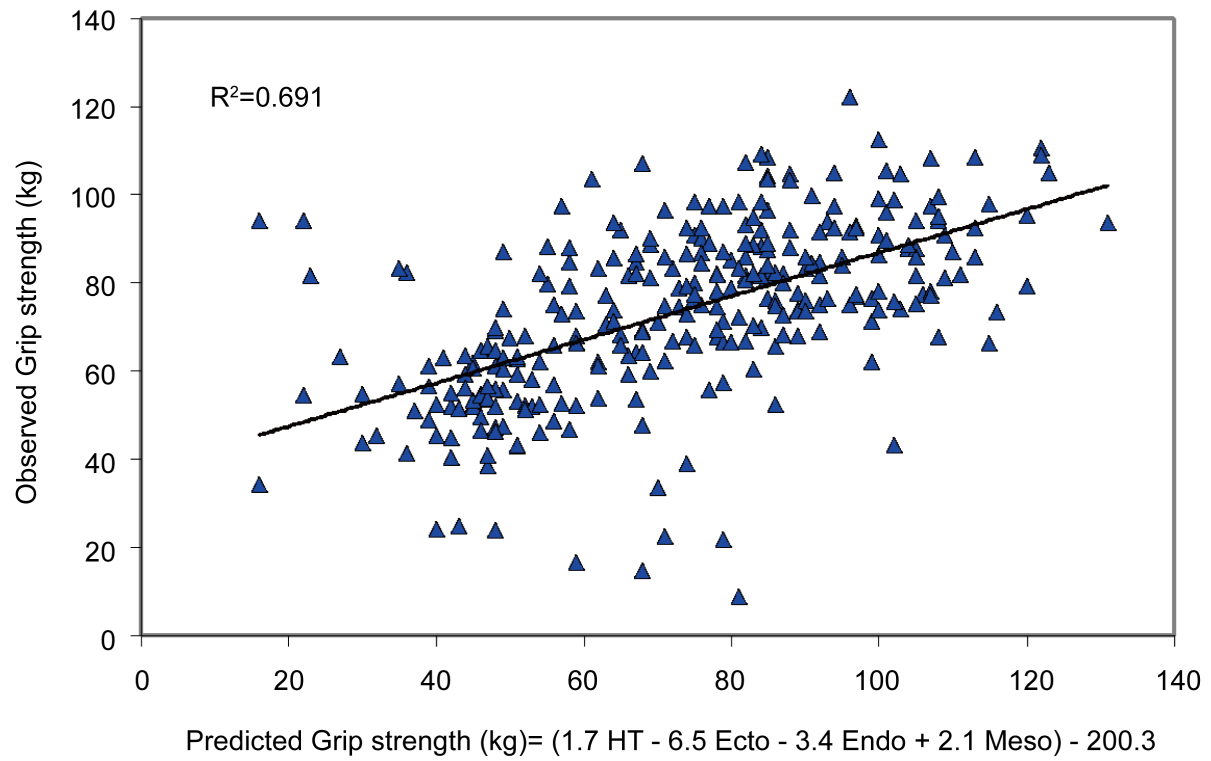

Figure 3. Correlation between observed Grip Strength and Grip Strength predicted from height $(\mathrm{cm})$ and somatotype components.

Flexibility was not significantly related to the measured variables. This functional characteristic of the joints is high in females and in young males, even when sedentary. It is maintained in physically active adult males but is lowest in sedentary adult males. It is not related to ectomorphy or to any other somatotype component.

\section{Conclusion}

Endomorphy is found to have a strongly negative influence on aerobic fitness levels. Grip strength depends much more on height than on somatotype components, while 
flexibility is found to be independent of somatotype and other anthropometric measurements.

\section{References}

[1] Rebato, E., Salces, I., Rosique, J., San Martín, L. and Susanne, C. (2000) Analysis of Sibling Resemblance in Anthropometric Somatotype Components. Annals of Human Biology, 27, 149-161. http://dx.doi.org/10.1080/030144600282262

[2] Peeters, M.W., Thomis, M.A., Loos, R.J., Derom, C.A., Fagard, R., Claessens, A.L., Vlietinck, R.F. and Beunen, G.P. (2007) Heritability of Somatotype Components: A Multivariate Analysis. International Journal of Obesity (London), 31, 1295-1301.

[3] Bolonchuk, W.W., Siders, W.A., Lykken, G.I. and Lukaski, H.C. (2000) Association of Dominant Somatotype of Men with Body Structure, Function during Exercise, and Nutritional Assessment. American Journal of Human Biology, 12, 167-180. http://dx.doi.org/10.1002/(SICI)1520-6300(200003/04)12:2<167::AID-AJHB2>3.0.CO;2-3

[4] Prior, B.M., Modlesky, C.M., Evans, E.M., Sloniger, M.A., Saunders, M.J., Lewis, R.D. and Cureton, K.J. (2001) Muscularity and the Density of the Fat-Free Mass in Athletes. Journal of Applied Physiology, 90, 1523-1531.

[5] Berg, K., Latin, R.W. and Coffey, C.J. (1998) Relationship of Somatotype and Physical Characteristics to Distance Running Performance in Middle Age Runners. The Journal of Sports Medicine and Physical Fitness, 38, 253-257.

[6] Gil, S.M., Gil, J., Ruiz, F., Irazusta, A. and Irazusta, J. (2007) Physiological and Anthropometric Characteristics of Young Soccer Players according to Their Playing Position: Relevance for the Selection Process. The Journal of Strength \& Conditioning Research, 21, 438445.

[7] Ramadan, J. and Barac Nieto, M. (2003) Reported Frequency of Physical Activity, Fitness, and Fatness in Kuwait. American Journal of Human Biology, 15, 514-521. http://dx.doi.org/10.1002/ajhb.10190

[8] Danis, A., Kyriazis, Y. and Klissouras, V. (2003) The Effect of Training in Male Prepubertal and Pubertal Monozygotic Twins. European Journal of Applied Physiology, 89, 309-318.

[9] Chaouachi, M., Chaouachi, A., Chamari, K., Chtara, M., Feki, Y., Amri, M. and Trudeau, F. (2005) Effects of Dominant Somatotype on Aerobic Capacity Trainability. British Journal of Sports Medicine, 39, 954-959. http://dx.doi.org/10.1136/bjsm.2005.019943

[10] Jürimäe, T. and Jürimäe, J. (1998) Anthropometric and Health-Related Fitness Characteristics in Middle-Aged Obese Women. Collegium Antropologicum, 22, 97-106.

[11] Keogh, J.W., Hume, P.A., Pearson, S.N. and Mellow, P. (2007) Anthropometric Dimensions of Male Powerlifters of Varying Body Mass. Journal of Sports Sciences, 25, 1365-1376. http://dx.doi.org/10.1080/02640410601059630

[12] Carter, J.E.L. (2002) Instruction Manual. San Diego State University, San Diego. 
Submit or recommend next manuscript to SCIRP and we will provide best service for you:

Accepting pre-submission inquiries through Email, Facebook, LinkedIn, Twitter, etc. A wide selection of journals (inclusive of 9 subjects, more than 200 journals)

Providing 24-hour high-quality service

User-friendly online submission system

Fair and swift peer-review system

Efficient typesetting and proofreading procedure

Display of the result of downloads and visits, as well as the number of cited articles

Maximum dissemination of your research work

Submit your manuscript at: http://papersubmission.scirp.org/

Or contact health@scirp.org 